\title{
Pedagogical approach in the implementation of curriculum programs in nurse training
}

\author{
Abordagem pedagógica na implementação de programas curriculares na formação do enfermeiro \\ Enfoque educativo en la aplicación de lo currículum en la formación en enfermería
}

Débora Maria Vargas Makuch ${ }^{1}$ Ivete Palmira Sanson Zagonel $^{1}$

1. Faculdades Pequeno Príncipe.

Curitiba, PR, Brazil.
Corresponding author:

Débora Maria Vargas Makuch.

E-mail: deboramakuch@hotmail.com

Submitted on $02 / 14 / 2017$

Accepted on 05/10/2017.

DOI: 10.1590/2177-9465-EAN-2017-0025

\section{Abstract}

Objective: To evaluate the trends of changes in the Pedagogical Approach axis in the training of nurse practitioners. Methods: Convergent research with a mixed approach, with 63 participants from 9 nursing schools from Curitiba and metropolitan area. Data collection followed the Focus Group technique. Results: In the Pedagogical Approach axis, $66.7 \%$ of the schools reached the Advanced typology (A) and 33.3\% reached the Innovative typology with an Advanced Trend (ItA). From the analysis of the thematic content, seven units of context emerged. Conclusions: The continuous process experience of commitment to human beings and their context gives autonomy to students. The problematization method is an effective teaching-learning strategy for the construction of comprehensiveness. Implications for practice: The knowledge of pedagogical trends favors changes in nurse's education in line with the profile of the graduates, established by the specific Brazilian Curriculum Guidelines for nursing practice, was confirmed as the intention of professors in this study.

Keywords: Teaching; Nursing; Schools, nursing

\section{Resumo}

Objetivo: Avaliar as tendências de mudanças no eixo Abordagem Pedagógica na formação do enfermeiro. Método: Pesquisa convergente com abordagem mista, com 63 participantes de 9 escolas de enfermagem de Curitiba e Região Metropolitana. A coleta de dados se deu pela técnica de Grupo Focal. Resultados: 66,7\% das escolas atingiram a tipologia Avançada e 33,3\% a tipologia Inovadora com tendência Avançada, no eixo Abordagem Pedagógica. Da análise de conteúdo temática, emergiram sete Unidades de Contexto. Conclusão: A vivência do processo contínuo de compromisso com o ser humano e seu contexto confere autonomia ao estudante e o transforma em agente ativo no processo de cuidar, sendo a problematização uma estratégia eficaz de ensino-aprendizagem, para a construção da integralidade. Implicações para a prática: $O$ conhecimento das tendências pedagógicas favorece mudanças na formação do enfermeiro compatíveis ao perfil do egresso proposto pelas Diretrizes Curriculares Nacionais da profissão, confirmou-se como intencionalidade dos docentes do estudo.

Palavras-chave: Ensino; Enfermagem; Escolas de Enfermagem.

\section{REsumen}

Objetivo: Evaluar las tendencias de cambios en el eje Enfoque Pedagógico en la formación del enfermero. Método: Investigación convergente con enfoque mixto, con 63 participantes de 9 escuelas de enfermería de Curitiba y Región Metropolitana. La obtención de datos fue conseguida por la técnica de Grupo Focal. Resultados: 66,7\% de las escuelas alcanzaron la tipología Avanzada y 33,3\% la tipología Innovadora con tendencia Avanzada, en el eje Enfoque Pedagógico. Del análisis del contenido temático, surgieron siete Unidades de Contexto. Conclusión: La vivencia del proceso continuo de compromiso con el ser humano y su contexto brinda autonomía al estudiante y lo transforma en agente activo en el proceso de cuidar, siendo la problematicidad una estrategia eficaz de enseñanza-aprendizaje, para la construcción de la integralidad. Implicaciones para la práctica: El conocimiento de las tendencias pedagógicas favorece los cambios en la formación del enfermero, compatibles con el perfil del egresado; propuesto por las Directrices Curriculares Nacionales de la profesión, se confirmó como intencionalidad de los docentes del estudio.

Palabras clave: Enseñanza; Enfermería; Escuelas de Enfermería. 


\section{INTRODUCTION}

Knowledge about the pedagogical trends that support the curriculum of nursing courses promotes changes towards the adjustment of qualification to current health demands. Following this line of thinking, "the most popular aspects comprising the healthy development of human life question the overly technical way to approach population health problems". 1:6

Health education needs to follow the changes imposed on society, which must be connected to population demands. Additionally, it shapes health professionals capable of working in agreement with the health care models recommended in the services, which presupposes qualification seeking comprehensiveness. As comprehensiveness is a polysemic concept, the incorporation of this paradigm by higher education students in the health area involves the transversality of the health-disease process, humanism, ethics and social inclusion.

Aiming to achieve the qualification of health professionals who are committed to the Sistema Único de Saúde (SUS - Unified Health System) principles, the responsibility and guarantee of care for individuals in all their dimensions should be strengthened, balancing out technical excellence and social relevance. $^{2}$

For students to experience the teaching-learning process in a dynamic, modern and active way, the existing pedagogical model must be reformulated. Moreover, this will occur with the implementation of a curriculum that enables the development of competences, which are established by the "Diretrizes Curriculares Nacionais" (DCN - Brazilian Curriculum Guidelines) for undergraduate courses in the health area. ${ }^{3}$

How the path followed by health curricula is expressed is distinct. However, there is the fact that care should be provided to individuals either through comprehensiveness or competences in the curriculum guidelines of health courses. These are not excluding, but complementary as they naturally integrate teaching and care, i.e. they achieve competences for comprehensiveness. ${ }^{2,3}$

Based on the previously mentioned analyses of curriculum guidelines, the competences established for the majority of health courses include the following: health care; decisionmaking; communication, leadership; administration and management; permanent education.

When the theme of trends in curriculum changes for higher education courses in nursing was approached in a study, ${ }^{4}$ it was found to follow paths that reveal the type of curriculum of each school, which is implemented according to the unique characteristics of each institution, but also the trend to focus that permeates the curricular proposal. This focus is understood as the basis guiding the curriculum, which is determined by different possibilities in general, considering the institutional mission, lines of thinking of the groups of professors working on the course, students' profile characteristics as proposed by the "Projeto Pedagógico de Curso" (PPC - Course Pedagogical Project), regional determinants for disease-health care and health system, among other aspects.
Thus, the present study deals with part of the Master's research project ${ }^{4}$ that used the "Instrument of Strategic View for Institutional Development of Undergraduate Health Courses". This instrument includes five relevant axes of the construction and execution of curriculum programs in medical schools, adapted to the nursing courses of the city of Curitiba and its metropolitan region. ${ }^{1}$

The proposed axes are representative of a process of construction of changes in the teaching institution towards comprehensiveness: The World of Work, Pedagogical Project, Pedagogical Approach, Sceneries of Practice, and Development of Professors. These axes are determined in vectors and thematic areas, which identify the curriculum typologies and classify them as Traditional, Innovative or Advanced.

This classification enables trends to be followed, "not only determining the movement towards the paradigm of comprehensiveness, but also guiding managers, professors and students about the process of implementation of the undergraduate course curriculum". 5:203

Based on what has been described, the present study aimed to assess the trends in changes to the Pedagogical Approach in nursing qualification in higher education institutions of the city of Curitiba and metropolitan area, using the instrument known as "Strategic View for Institutional Development of Undergraduate Health Courses". ${ }^{1}$ This study shows the results of the Pedagogical Approach axis in the group of following axes of nursing courses: Curriculum Structure; Educational Guidance; and Support and Tutoring.

\section{METHODS}

The present study adopted convergent research with a mixed approach. ${ }^{6}$ It was approved by the CEP/FPP (the institution's Research Ethics Committee) under official opinion number 1169628. Study participants included 43 professors, 11 students and nine undergraduate nursing course coordinators from nine higher education institutions of the city of Curitiba and metropolitan area.

Of all 50 nursing schools in the state of Paraná, 13 were situated in Curitiba, one in Araucária and one in Campo Largo. According to data from the Ministry of Education, three of them are not recognized by the MEC (Ministry of Education and Culture) and one does not perform activities any longer, thus resulting in 11 higher education institutions. ${ }^{7}$ When the course coordinator of each institution was initially contacted, two of them did not authorize the study to be performed, thus totaling nine participants. The coordinators who agreed to participate in this study were responsible for the group formation in their institution.

Data collection occurred simultaneously through the focus group technique, when the research instrument was applied. The analysis considered each of the axes included in the instrument, which are guided by vectors that, in their turn, show the three following alternative situations: A) the innermost circle - a traditional situation of the Flexnerian model; B) the intermediate circle - an intermediate situation of innovation; and C) the 
outermost circle - an advanced situation for transformations, aimed at the comprehensiveness and health care model from the Curriculum Guidelines.

The set of five axes with their vectors moves from a position considered to be conservative and traditional (first alternative shown in the instrument in the innermost circle) to an intermediate and innovative one (second alternative) and finally to a more advanced one (third alternative). As nursing schools see themselves in more advanced positions in the alternatives, the radial model is gradually filled with a percentage variation from $33 \%$ to $100 \%$, the former being a conservative and traditional alternative and the latter being an advanced perception for changes, seeking comprehensiveness (Figure 1).

Figure 1. Radial model representing the $A, B$ and $C$ levels that refer to the alternatives of each sector comprising the five conceptual axes proposed by Lampert. Source: Lampert (2009).

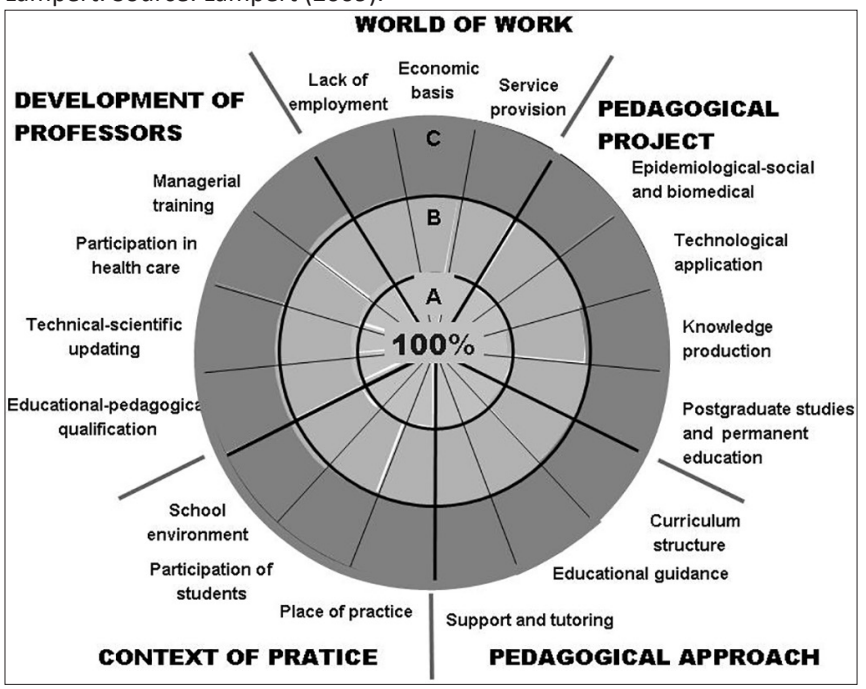

The quantification of the school's area of expansion in the construction of the paradigm of comprehensiveness considers the $20 \%$ weight for each of the five relevant conceptual axes, totaling $100 \%$. The axis value is characterized by the sum of its vectors, which also receive weights that, when added, result in the totality of the axis, that is, $100 \%{ }^{1}$

The identification of the types of school occurred through the quantification of axes and vectors, considering school expansion in representative percentage values: Traditional (up to 59\%), Innovative with a Traditional (60 to $69 \%$ ), Innovative with an Advanced Tendency (70 to $79 \%$ ), and Advanced (80 to $100 \%$ ).

Following the steps of the technique of thematic content analysis, ${ }^{8}$ reports originated from Focus Group meetings were organized and categorized according to thorough reading and identification of relevant points and main ideas about this theme. At this moment, subcategories and categories were selected, considering the vectors and axes proposed by Lampert.

\section{RESULTS}

The results of the present study show the perception of participants in percentages for a group of nine nursing schools, in terms of the trends of change to the Pedagogical Approach.

In the Curriculum Structure vector, of all nine schools analyzed, five $(55.6 \%)$ chose alternative C, "has a largely integrated curriculum, areas of real practice in adult and maternalchild care, family health and labor medicine, among others" and four $(44.4 \%)$ chose alternative B, "has integrating disciplinesactivities throughout the first years, although maintaining the basic and professionalizing cycle organization with fragmented disciplines". None of the schools chose option A, "has basic and professionalizing cycles that are separated and organized into fragmented disciplines".

It should be emphasized that no schools participating in the present study had a curriculum structure comprised of basic and professionalizing cycles organized into fragmented disciplines.

Regarding the Educational Guidance vector, $100 \%$ of schools selected alternative $\mathrm{C}$, "adopts active learning methods with an emphasis on health reality and a multi-disciplinary approach, apart from using community services and spaces in practice, assessing knowledge, abilities and attitudes while encouraging an interactive assessment and self-assessment". None of the schools chose alternative A, "emphasizes theoretical classes in isolated disciplines and practical classes are mainly demonstrative and centered on the professor, including written assessment based on memorization", or alternative $\mathrm{B}$, "emphasizes theoretical classes with some multidiscipline integration and practical classes are centered on hospital-oriented skills with an assessment of clinical knowledge and abilities".

Regarding the Support and Tutoring vector, of all nine schools analyzed, six (66.7\%) chose alternative B, "enables reasonable physical and material conditions of support for teaching-learning and offers teaching performed in small groups in turns for several disciplines", and three (33.3\%) selected alternative C, "enables adequate conditions of physical and material spaces of support for the development of the teaching-learning process and provides tutoring with analysis and solution to problems based on real situations". None of the schools selected alternative A, "does not provide adequate physical or material conditions of support for teaching-learning (library, classrooms, specific laboratories, and audio-visual and computer resources, among others) and does not offer tutoring".

In the Pedagogical Approach axis, $66.7 \%$ of schools achieved the Advanced typology $(A)$ and $33.3 \%$ achieved the Innovative typology with an Advanced Trend (ItA). (Table 1)

After typologies were analyzed, thematic content analysis was performed with focus groups, following the steps recommended by the author. ${ }^{7}$ 
Table 1. Identification of the typologies of the Pedagogical Approach axis among the nine Nursing Schools in the city of Curitiba and Metropolitan Area, Southern Brazil.

\section{PEDAGOGICAL APPROACH}

\section{TYPOLOGY}

\begin{tabular}{|llcc} 
& & N & $\%$ \\
\hline A & Advanced & 6 & 66.7 \\
\hline la & Innovative with an advanced trend & 3 & 33.3 \\
It & Innovative with a traditional trend & 0 & 0 \\
\hline T & Traditional & 0 & 0 \\
\hline & TOTAL & 9 & 100 \\
\hline
\end{tabular}

Source: Research data.

In the Pedagogical Approach category and Curriculum Structure subcategory, the following two units of context emerged: matrix integrated with a teaching proposal and curriculum matrix organized into basic and professionalizing cycles, as shown in Figure 2.

Figure 2. Representation of the Pedagogical Approach category and Curriculum Structure subcategory, based on discourses from all schools. City of Curitiba, Southern Brazil, 2016. Source: Authors.

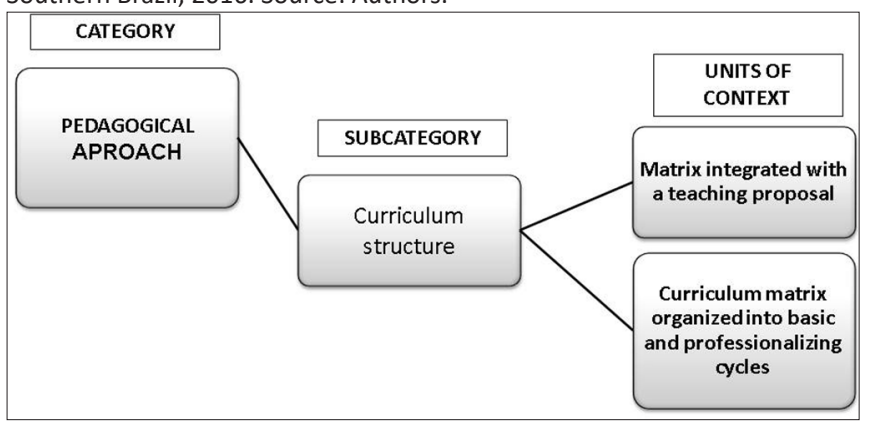

In general, the lack of agreement between the established curriculum program and the expected curriculum model was observed in nursing qualification. Discussions about the curriculum structure evidenced the matrix integrated with a teaching purpose, characterized by the promotion of academic work integrated through its integration with certain disciplines and through the reorganization of common contents, avoiding redundancy of themes.

[...] in the new 2015 curriculum, $68 \%$ of the first period is integrated, while the second period is expected to reach $78 \%$. However, as it develops into the third, fourth periods, the number of integrated disciplines decreases substantially due to the characteristics of clinical teaching themselves [...]. There's a group effort being made to gradually increase this (C1-IES1).
The speech of professors reveals a trend towards discipline integration. However, the curriculum matrix organized into basic and professionalizing cycles is still maintained, with reports that discipline segregation causes knowledge to be fragmented, thus hindering students' ability to connect types of knowledge.

[...] I think that these disciplines with integrated activities are developing, because speech itself segregates the parts. We talk about the technical nature and forget our basic integration. So there's a barrier here, as we continue to be integrated, but we're not there yet [...]. We're halfway through, but we can't make this connection yet. Because when I say that it's integrated, it means there aren't fragments anymore, it's whole. There's no separation between basic and professionalizing (D5-IES2).

In the "Educational Guidance" subcategory, the following two units of context arose: use of active teaching methods aimed at meaningful learning and assessment process compatible with the teaching method used. (Figure 3)

Figure 3. Representation of the Pedagogical Approach category and Educational Guidance subcategory, according to discourses from all schools. City of Curitiba, Southern Brazil, 2016. Source: Authors.

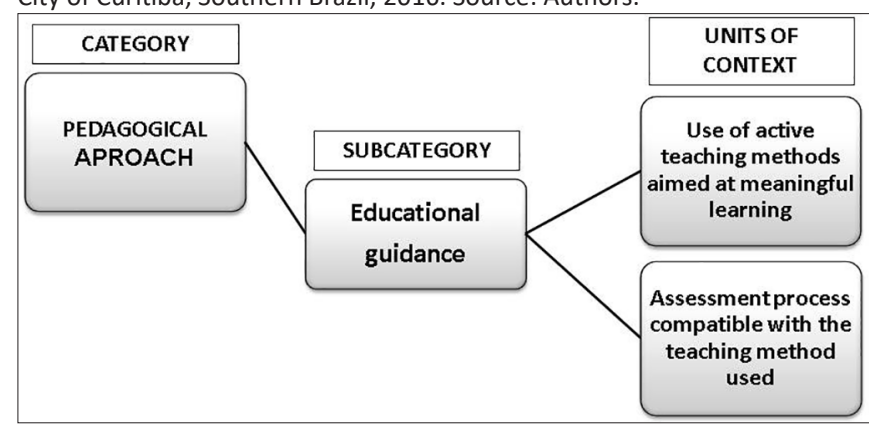

Participants' reports evidenced the use of active teaching methods aimed at meaningful learning, which is expressed by one of the professors as "the students' need to make connections and interrelations". Students' active participation and the construction of knowledge through the contextualization of reality are also approached. There were reports on problematization as a method frequently used by schools, as this enables a critical analysis of the social and health context of the community, in addition to encouraging team work and decision-making.

In most of our practices, we use several methods for students to be the main participants, at least this is the intention [...] I believe the question of learning with active methods is that students must make interrelations and connections and they can learn a little more every year in this respect. This is what we've tried (D5-IES5). 
Based on reports on the relevance of the use of active teaching methodologies, the critical reflection on the assessment process compatible with the teaching methodology used arose. Professors were found to be restless with the ways to assess knowledge, skills and attitude, especially interactive assessment and self-assessment, which is usually performed by some schools at the end of field practices. Self-assessment is mentioned in students ' speech as an "enriching moment".

[...] they changed the assessment tools last year, which also made us, students, assess ourselves and this is quite enriching (E3-IES1).

[...] in addition, in practical terms, we promote selfassessment [...] we have to provide this to students, even if they're still developing, and work for them to understand themselves in this self-assessment process, encouraging them to develop several activities and also assess themselves (D4-IES5).

In the Support and Tutoring subcategory, the following three units of context arose: adequacy of physical space as a facilitator of the teaching-learning process; study on clinical cases and problem-based learning; and concepts and meaning of tutoring. (Figure 4)

Figure 4. Representation of the Pedagogical Approach category and Support and Tutoring subcategory, according to discourses from all schools. City of Curitiba, Southern Brazil, 2016. Source: Authors.

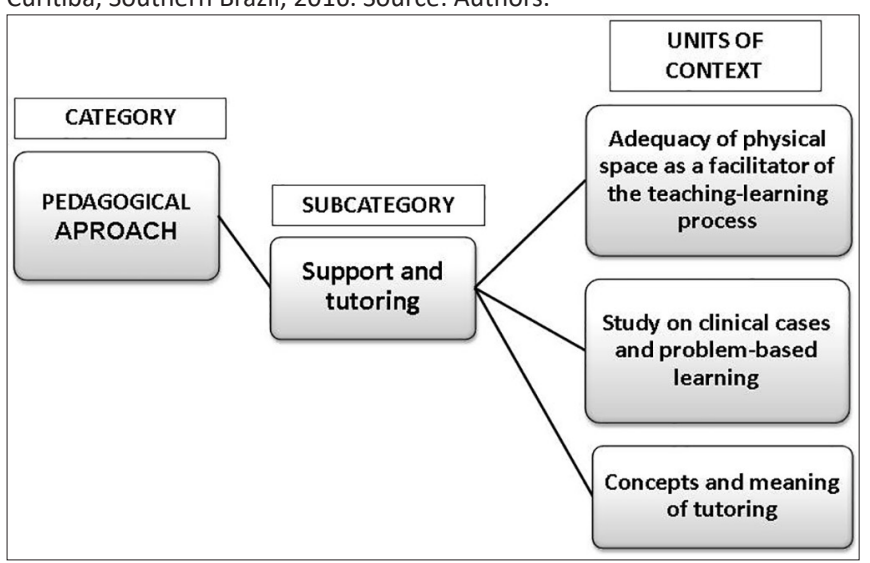

When the benefits of resources, support materials and teaching methodologies that promote meaningful learning are emphasized, the discussion about adequacy of physical space as a facilitator of the teaching-learning process emerged. This highlighted the organization of students in smaller groups for practice and training, thus requiring a sufficient number of rooms and laboratories and the change in the classroom layout for a non-linear configuration, which would facilitate the professorstudent relationship:
[...] the concept of classroom itself is changing. Some already have a round table for group work and we can see the need for such reformulation (C1-IES4).

Participants' speech showed some inaccuracy in terms of teaching methodologies through the study on clinical cases and problem-based learning ( $P B L)$, because none of the schools analyzed uses PBL, a method that some participants are not familiar with, thus indicating this to be similar to the problematization method. PBL has been viewed as the method which is currently used in some curriculum programs of the medical course and also applied by some professors in an isolated way. The fact that all schools selected option $\mathrm{C}$ was because they considered themselves to have adequate physical conditions and support materials from institutions. However, as they do not use the PBL, they mistake this teaching-learning method for problematization, which works with the analysis and solution of problems based on real situations:

[...] in my opinion, we have adequate conditions, physical space and materials, so that B wouldn't fit. However, we don't work with PBL, so this is why I went for B. But I don't agree with it, conditions are very adequate (D4-IES6).

Regarding the concept and meaning of tutoring, there is the wrong concept that the term "tutoring" is synonym with "monitoring", like the division of classes into smaller groups and like the time spent out of the classroom and answering questions. The practice of tutoring as support for students with problems was equally taken into consideration.

[...] we have tutoring according to the classes, tutors who work with small groups. We have professors who are responsible for students and we try to minimize the problems with the students as much as possible, so they bring these to the tutor, the tutor assesses them and tries to use common sense. So it's based on reality and this is why I chose C [...] (D3-IES6).

\section{DISCUSSION}

The organization of knowledge through the curriculum is a cultural and historical practice, which is also socially influenced by policies, management processes, customs, ideologies and theories that will become rules for the pedagogical practice. ${ }^{9}$

Curriculum structure is not a static process, as content selection through conceptual and methodological choices expresses the world conception in student qualification. This concept is influenced by constant social changes. ${ }^{10}$

Pedagogical practice aimed at transdisciplinarity, which can be understood as one of the repercussions of the complexity paradigm, the beginning of transformation towards overcoming 
curriculum models with parallel and even overlapping disciplines, although lacking real integration. ${ }^{11}$

The need for curriculum integration in health education is practically unanimous. However, it is important to pay attention to the levels of integration described by Fogarty (1991), which can be gradually applied by schools. These levels of integration vary from "the least integrated" (discipline fragmentation) to "the most advanced" (network-connected curriculum).

Steady development is possible between these levels, from connections made by professors themselves, even in isolated disciplines, to the use of what is known as an integrating discipline, which deliberately starts from thematic or problemsituations that "align cognitive domains, abilities, attitudes, thoughts and culture in an approach of multiple 'intelligences' to teach through disciplines". 12:268

Considering the movement of the Brazilian Curriculum Guidelines for Nursing in the restructuring of university curriculum programs, aimed at meeting the new professional requirements determined by competences and abilities, which must be followed by all qualifying institutions in this country, the implementation of the integrated curriculum stands out. This is a way to group the assumptions of "globalization, interdisciplinarity, knowledge and social, economic and political interrelations". 13:315

The Curriculum Guidelines for Nursing primarily aim at the flexibility of the curriculum and solid qualification, according to the knowledge gained in each area. This enables students to contextualize changes in the health area and their repercussions in the workplace, promoting the general, technical, scientific, humanistic, critical and reflective professional profiles, ready to work on different health care levels.

The logic that permeates the construction of an integrated curriculum is the possibility of themes that are relevant for what are known as primary areas to become the means for decisionmaking and problem-solution, as they are organized in modules, not individually. ${ }^{14}$

Health-area courses inherited the discipline-based curriculum structure organization, beginning with the theory and subsequently approaching practical situations, assuming that students will automatically apply what they have studied in an adequate way, moving from the abstract to the concrete. , $^{9,14-16}$

Pedagogical evolutionary principles, clinical development, health realities and social forces can promote curriculum reforms. "However, how we teach and what we teach are probably less important than the environment we create to facilitate a partnership between professors and students", 17:52 a partnership evidenced as a horizontal relationship, where professors enable learning in an intermediating environment. ${ }^{18}$

The relationships between participants of the teachinglearning process still originate from the presupposed verticalization, which becomes concrete through the knowledge transmitted by the ones who have it to those who do not. Knowledge production occurs precisely through complementarity and diversity of the professor-student relationship, where the autonomy of those involved is preserved. ${ }^{17}$
For the horizontality of learning relationships to be effective, the distribution of students in small tutoring groups is proven evidence, as the relationships established in tutoring with the use of real or simulated situations of professional practice promote social skills and guarantee the development of competences and construction of new knowledge..$^{19,20}$ One should take into consideration "the establishment of networks of relationships that enable students to be free to act with commitment and responsibility" in the perspective of construction of their autonomy as nurses. ${ }^{21: 21}$

This "network of relationships" can occur as peer mentoring, which is a model of tutoring through which students in the beginning of their professional qualification are followed by students who are more experienced and advanced in the qualification process. ${ }^{22}$

This model was developed in the 1970s in American nursing schools. It "provides academic and personal support", enabling the construction of a "competent professional practice from the technical, ethical and human perspective". 23:716

Considering the fact that the undergraduate course is only one of the steps of the qualification process, tutoring and mentoring strategies are facilitators in the construction of the professional identity and profile expected from graduates, in addition to enabling new ways to acquire knowledge. Students should be able to learn how to learn, as knowledge and competences for professional activity change throughout time.

Thus, "it is essential to think about a methodology for a liberating educational practice in the qualification of active professionals". ${ }^{24: 298}$ To achieve this, the use of active teaching methodologies improve meaningful contextualized learning, ethical formation and the development of the clinical reasoning.

The adoption of active learning methods presupposes meaningful learning, when knowledge acquisition surpasses the simple acquisition of information, because "school knowledge will require university students to be challenged by the theoreticalpractical scientific context of the area studied, as they come closer to reality". $25: 22$ The objectives of learning are revealed in the student's autonomy construction process. This process is mediated by professors and it enables the development of an open, flexible and mature culture for knowledge and action.

To achieve this, the acquisition of competences, here translated as the "knowledge, ability and attitude" consensus as it is triggered in an active process of professional qualification, presupposes "know-how", which is structured into three dimensions: conceptual, interpersonal and technical skills. These dimensions imply decision-making, problem analysis and formulation, values and attitudes..$^{20: 725}$

In this context of construction of students' autonomy, traditional ways of assessment represented by theoretical tests with scores given by professors do not describe the learning process meaningfully. The assessment of active strategies "must correspond to a way for students themselves to follow their movement towards acquisition and the product acquired". Thus, 
an interactive assessment and self-assessment are important, enabling students to have a perspective of their development and the "return to actions that need to be better trained and/or complemented". 25:25

The effectiveness of the assessment does not only occur through the eyes of professors. Thus, other perspectives are taken into consideration, whether from their colleagues or students themselves. In addition to allowing the "awareness of the learning development", self-assessment improves critical-reflective thinking, a profile expected from graduates. Regarding peer assessment, although subject to subjectivity and the influence of personal opinions about their colleague, this assessment is an important performance indicator, provided that reports remain anonymous and that this is performed through a structured instrument. Inter-peer assessment can lead to positive changes in student behavior. ${ }^{26: 42}$

The reference of meaningful learning, which has been previously approached and in which the use of active methods adopts the potentially significant content and a favorable learning attitude as presuppositions for knowledge acquisition.

Based on this assumption, the functionality of the new content stands out, which could even be memorized. However, if students do not see the contextual relationships and their application, the foundation will not be laid, because it is "in the reflection and theorization, originated from the actions of professional practice, preferably performed in actual work situations, that students and professors construct and develop their abilities". 19:374

Regarding the potentialities and vulnerabilities of the problem-based learning (PBL) method in undergraduate nursing courses, evidence points out that the distribution of students into small tutoring groups enables the approach to communicative skills and inter-disciplinary work. This requires responsibility, communicative skills, alliance, integration, adaptation to changes, tolerance and management of uncertainty. ${ }^{20}$

The relationships established in tutoring and the use of real or simulated situations of professional practice promote social skills and guarantee the development of competences and the construction of new knowledge. ${ }^{19,20}$

Although three out of the nine schools affirmed that they offer tutoring with problem analysis and solution based on real situations, it should be emphasized that none of the nursing courses analyzed includes a curriculum comprised of competences with the PBL method, which enables the inclusion of tutoring (small groups).

\section{CONCLUSIONS AND IMPLICATIONS FOR THE PRACTICE}

The implementation of pedagogical practices aimed at nursing qualification, in agreement with the profile of graduates recommended by the specific Curriculum Guidelines for this profession, was confirmed through the professors' intention in this study.
The reflective process resulting from the focus group discussion enabled us to observe the trends of changes in the Pedagogical Approach axis in nursing qualification in curriculum programs implemented by higher education institutions. Additionally, when classifying the profile of schools as advanced (A), representative groups outlined the pedagogical profile of undergraduate nursing schools of the selected area.

The Focus Group composition with a smaller number of participants could be considered as a limitation of this study, as it did not include a deeper reflection of questions that involve the teaching-learning process. Another limitation could be the presence of the Focus Group coordinator, which at times inhibited professors from expressing themselves freely or even changing their choice at the moment of responding to the instrument individually, when consensus was reached.

The experience of the continuous process of construction and commitment to human beings and their context in the teaching-service interaction provides autonomy to students and transform them into active participants of the health care process. This also occurs through new ways to teach and problematization is an efficient teaching-learning strategy for the construction of comprehensiveness in the perspective of professors.

Health care comprehensiveness takes place through the multi-professional and inter-disciplinary relationship in the group dimension, but also through community participation in the decisions in public health policies.

For the ideal of comprehensiveness to be achieved, health care must be redesigned in the several health service spaces, primary health units, and highly specialized services, as must be policy making and management.

The assessment of higher education institutions is an important aspect, as the results have an impact on decision making for the learning process. In this way, through the dialogue between professors and students, it is possible to improve, transform or implement new assessment strategies to identify the potentialities obtained or to overcome possible obstacles to the development of pedagogical actions.

Additionally, schools must use methodologies aimed at meaningful learning and the active participation of students in this process. The construction of "know-how" and "how to do" is feasible through practical classes, simulation, dramatization, demonstration, seminars, group discussions, planned studies, internship follow-up, study groups, problem resolution, visits and actions in practical contexts. This group of strategies or those that can be implemented by schools need to be offered in an integrated and cross-sectional way throughout the course.

None of the schools participating in this study saw themselves in a curriculum structure comprised of basic and professionalizing cycles organized in fragmented disciplines.

The changes to the professional qualification context in higher education have a direct influence on the qualification of professors of undergraduate courses in its several perspectives. In this sense, constant concern for the qualification of professors 
is required. Professors must reflect on the three pillars on which the exercise of teaching is constructed: scientific knowledge (epistemological dimension), teaching knowledge (pedagogical dimension) and contextualized socializing knowledge (politicalsocial dimension). Moreover, they must be aware of their role as mediators/facilitators in the teaching-learning process.

As one of the aspects that direct definitions, principles and foundations for the qualification of nurses for the health system and job market, the Brazilian Curriculum Guidelines promote and level the previously described competences in their principles, guiding schools in terms of organization, integration, development and assessment of their curriculum programs.

\section{REFERENCES}

1. Lampert JB, Aguilar-da-Silva RH, Perim GL, Stella RCR, Abdalla IG, Costa NMSC. Project for the evaluation of change trends in the undergraduate course of Brazilian medical schools. Rev Bras Educ Med [Internet]. 2009; [cited 2015 Oct 18]; 33(Supl.1):5-18. Available from: http://dx.doi.org/10.1590/S0100-55022009000500002

2. Albuquerque VS, Tanji S, Silva CMSMLD, Moço ETM, Felippe KC, Miranda JFA. Integração curricular na formação superior em saúde: refletindo sobre o processo de mudança nos cursos do Unifeso. Rev Bras Educ Med [Internet]. 2007 Sep/Dec; [cited 2015 Jul 20]; 31(3):296303. Available from: http://www.scielo.br/scielo.php?script=sci_arttext \&pid=S0100-55022007000300013. http://dx.doi.org/10.1590/S010055022007000300013

3. Bollela VR, Machado JLM. Internato baseado em competências: bridging the gaps [Internet]. São Paulo: Med Vance; 2010. 99 p.

4. Makuch DMV. Tendências de mudanças na implementação de programas curriculares da graduação de enfermagem em Curitiba $e$ Região Metropolitana [Dissertation]. Curitiba: Faculdades Pequeno Príncipe; 2016. $296 \mathrm{f}$.

5. Lampert JB. Tendências de mudanças na formação médica no Brasil [Thesis]. Rio de Janeiro: Escola Nacional de Saúde Pública, Fundação Osvaldo Cruz, Ministério da Saúde; 2002. 219 p.

6. Creswell JW, Clark VLP. Pesquisa de métodos mistos. 2a ed. Porto Alegre: Penso; 2013. 288 p.

7. Ministério da Educação (BR). Instituições de Ensino Superior Credenciadas [e-MEC register], Brasília (DF): Ministério da Educação; Available from: http://portal.mec.gov.br/instituicoes-credenciadas

8. Minayo MCS. O desafio do conhecimento: pesquisa qualitativa em saúde. 11a ed. São Paulo: Hucitec; 2008.

9. Braid LMC, Machado MFAS, Aranha AC. Estado da arte das pesquisas sobre currículo em cursos de formação de profissionais da área da saúde: um levantamento a partir de artigos publicados entre 2005 e 2011. Interface (Botucatu) [Internet]. 2012 Jul/Sep; [cited 2015 Jul 20]; 16(42):679-92. Available from: http://www.scielo.br/scielo. php? script=sci_arttext\&pid=S1414-32832012000300008\&lng=en http://dx.doi.org/10.1590/S1414-32832012000300008

10. Xavier LN, Oliveira GL, Gomes AA, Machado MFAS, Eloia SMC. Analisando as metodologias ativas na formação dos profissionais de saúde: uma revisão integrativa. SANNARE [Internet]. $2014 \mathrm{Jan} /$ Jun; [cited 2017 May 6]; 13(1):76-83. Available from: https://sanare. emnuvens.com.br/sanare/article/download/436/291

11. Torres PL, Behrens MA, Matos EM. Prática pedagógica numa visão complexa na educação presencial e a distância: os 'REAS' como recurso para pesquisar, ensinar e aprender. Rev Diálogo Educ [Internet] 2015 May/Aug; [cited 2017 May 6]; 15(45):443-71. Available from: http:// www2.pucpr.br/reol/index.php/dialogo?dd99=pdf\&dd1=15317. DOl: 10.7213/dialogo.educ.15.045.DS04
12. Iglésias AG, Bollela VR. Integração curricular: um desafio para os cursos de graduação da área da Saúde. Medicina (Ribeirão Preto) [Internet]. 2015; [cited 2015 Oct 18]; 48(3):265-72. Available from: http://revista.fmrp.usp.br/2015/vol48n3/simp8_Integracao-curricularna-area-da-saude.pdf. http://dx.doi.org/10.11606/issn.2176-7262. v48i3p265-272

13. Opitz SP, Martins JT, Telles Filho PCP, Silva AEBC, Teixeira TCA. O currículo integrado na graduação em enfermagem: entre o ethos tradicional e o de ruptura. Rev Gaúcha Enferm [Internet]. 2008 Jun [cited 2015 Mar 12]; 29(2):314-9. Available from: http://seer.ufrgs.br/ index.php/RevistaGauchadeEnfermagem/article/view/5598/3207

14. Silva MJ, Sousa EM, Freitas CL. Formação em enfermagem: interface entre as diretrizes curriculares e os conteúdos de atenção básica. Rev Bras Enferm. [Internet]. $2011 \mathrm{Mar} /$ Apr; [cited 2015 Oct 18]; 64(2):31521. Available from: http://www.scielo.br/scielo.php?script=sci_arttext \&pid=S0034-71672011000200015. http://dx.doi.org/10.1590/S003471672011000200015

15. Santos SSC. Currículos de enfermagem do Brasil e as diretrizes novas perspectivas. Rev Bras Enferm [Internet]. 2003 Jul/Aug; [cited 2015 Oct 18]; 56(4):361-4. Available from: http://www.scielo.br/scielo. php? script=sci_arttext\&pid=S0034-71672003000400009\&lng=en . http://dx.doi.org/10.1590/S0034-71672003000400009

16. Silva MG, Fernandes JD, Teixeira GAS, Silva RMO. Processo de formação da(o) enfermeira(o) na contemporaneidade: desafios e perspectivas. Texto Contexto-Enferm. [Internet]. 2010 Jan/Mar; [cited 2015 Oct 18]; 19(1):176-84. Available from: http://www.scielo.br/scielo. php?script=sci_arttext\&pid=S0104-07072010000100021\&lng=en . http://dx.doi.org/10.1590/S0104-07072010000100021

17. Dienstag JL. Evolution of the New Pathway curriculum at Harvard Medical School: the new integrated curriculum. Perspect Biol Med [Internet]. 2011; [cited 2015 Mar 12]; 54(1):36-54. Available from: http:// muse.jhu.edu/journals/pbm/summary/v054/54.1.dienstag.html. DOl: 10.1353/pbm.2011.0003

18. Lino MM, Backes VMS, Ferraz F, Reibnitz KS, Martini JG. Posturas pedagógicas adotadas no ensino de enfermagem e saúde na Região Sul do Brasil. Rev Bras Enferm [Internet]. 2011 Jan/Feb; [cited 2015 Oct 18]; 64(1):152-9. Available from: http://www.scielo.br/scielo. php?script=sci_arttext\&pid=S0034-71672011000100022\&lng=en . http://dx.doi.org/10.1590/S0034-71672011000100022

19. Lima VV. Competência: distintas abordagens e implicações na formação de profissionais de saúde. Interface (Botucatu) [Internet] $2005 \mathrm{Mar} /$ Aug; [cited 2015 Oct 18]; 9(17):369-79. Available from: http://www.scielo.br/scielo.php?script=sci_arttext\&pid=S141432832005000200012\&lng=en. http://dx.doi.org/10.1590/S141432832005000200012

20. Cónsul-Gribet M, Medina-Moya JL. Pontos fortes e deficiências da Aprendizagem Baseada em Problemas sob a perspectiva profissional de enfermeiras. Rev Latino-Am. Enfermagem [Internet]. $2014 \mathrm{Sep} /$ Oct; [cited 2015 Dec 02]; 22(5):724-30. Available from: http://www. scielo.br/pdf/rlae/v22n5/pt_0104-1169-rlae-22-05-00724.pdf. DOI: 10.1590/0104-1169.3236.2473

21. Meira MDD, Kurcgant P. Educação em enfermagem: avaliação da formação por egressos, empregadores e docentes. Rev Bras Enferm [Internet]. 2016; [cited 2016 Apr 21]; 69(1):10-5. Available from: http:// www.scielo.br/pdf/reben/v69n1/0034-7167-reben-69-01-0016.pdf. DOI: http://dx.doi.org/10.1590/0034-7167.2016690102i

22. Chaves LJ, Gonçalves ECQ, Ladeira LR, Ribeiro MS, Costa MB Ramos AAM. Tutoria como estratégia educacional no ensino médico. Rev Bras Educ Méd [Internet]. 2014; [cited 2015 Oct 18];38(4):53241. Available from: http://www.scielo.br/scielo. php?pid=S010055022014000400015\&script=sci_abstract\&tlng=pt. http://dx.doi. org/10.1590/S0100-55022014000400015

23. Martins AF, Bellodi PL. Mentoring: uma vivência de humanização $e$ desenvolvimento no curso médico. Interface (Botucatu) [Internet] 2016; [cited 2016 Aug 01]; 20(58):715-26. Available from: http://www. scielo.br/pdf/icse/v20n58/1807-5762-icse-1807-576220150432.pdf. DOI: $10.1590 / 1807-57622015.0432$ 
24. Vieira LM, Sgavioli CAPP, Simionato EMRS, Inoue ESY, Heubel MTCD, De Conti MHS, et al. Formação profissional e integração com a rede básica de saúde. Trab Educ Saúde [Internet]. 2016 Jan/Mar; [cited 2016 Apr 23]; 14(1):293-304. Available from: http://www.scielo.br/scielo. php?script=sci_arttext\&pid=S1981-77462016000100293. http://dx.doi. org/10.1590/1981-7746-sip00093
25. Anastasiou LGC. Metodologia ativa, avaliação, metacognição e ignorância perigosa: elementos para reflexão na docência universitária. Espaç Saúde [Internet]. 2014 Jun; [cited 2015 Oct 18]; 15(1):19-34. Available from: http://www.inesco.org.br/eventos/forum/anais/REpS_ ANAIS\%20DO\%20VII\%20FORUM\%20NACIONAL.pdf

26. Zeferino AMB, Passeri SMRR. Avaliação da aprendizagem do estudante. Cade ABEM [Internet]. 2007 Oct; [cited 2015 Oct 18]; 3:39-43. Available from: https://www.medicina.ufg.br/up/148/o/AVALIACAO_DA_ APRENDIZAGEM.pdf 